\title{
Neuroendocrine Properties of Adrenocortical Cells
}

\author{
M. Ehrhart-Bornstein ', U. Hilbers ${ }^{2}$ \\ 1 National Institute of Health, Bethesda, MD, USA \\ 2 Department of Internal Medicine III, University of Leipzig, Germany
}

Recent data suggest that adrenocortical cells under pathological as well as under physiological conditions show neuroendocrine properties. Within the normal adrenal, this neuroendocrine differentiation seems to be restricted to cells of the zona glomerulosa and might be important for an autocrine regulation of adrenocortical function. In addition, such neuroendocrine differentiation is a common phenomenon in adrenocortical carcinomas and is therefore of clinical importance. In our studies, the expression of neuronal cell adhesion molecule (NCAM) could be shown in the zona glomerulosa of the normal human adrenal and in the human adrenocortical cell line $\mathrm{NCl}-\mathrm{H} 295$ that also produces synaptophysin, a synaptic vesicle associated protein. In this chapter, data on neuroendocrine characteristics of adrenocortical cells are summarized and discussed.

Key words: Adrenal Cortex - Adrenal Carcinoma - NCl-H295 - Neuroeondocrine Differentiation - Neuronal Cell Adhesion Molecule (NCAM) - Synaptophysin

\section{Introduction}

Without doubt, adrenocortical steroidogenesis is, besides the regulation via the hypothalamus-pituitary-adrenal (HPA) axis, under the paracrine influence of locally produced factors. These factors are produced by adrenomedullary chromaffin cells (1), by immune cells, nerves and the vascular system (articles in this issue, [2]). However, several of these factors that influence adrenocortical steroidogenesis are, in addition, produced by adrenocortical cells themselves. Adrenocortical cells have been shown to produce cytokines such as IL-1, IL-6 and TNF $\alpha$ (articles by Marx et al. and Judd in this issue), and a local RAS system was idendified in the zona glomerulosa (see article by Mulrow in this issue). In addition, there is increasing evidence that adrenocortical cells could also show a neuroendocrine differentiation.

\section{Neuroendocrine differentiation in adrenocortical carcinomas}

A neuroendocrine differentiation of adrenocortical cells first became obvious in adrenocortical carcinomas. Histology and

Horm. Metab. Res. 30 (1998) 436-439

(c) Georg Thieme Verlag Stuttgart · New York electron microscopy are frequently used to characterize adrenal tumors $(3,4)$. The immunohistochemical characterization of cortical versus medullary tumors provided evidence for the expression of proteins by adrenocortical tumours that are typically expressed by neuroendocrine cells. These include synaptophysin, neuronal cell adhesion molecule (NCAM), neuronspecific enolase (NSE) and neurofilaments $(3,5,6)$. These proteins are located in different cellular compartments such as the cytoplasm (NSE), the membrane of secretory vesicles (synaptophysin) or the cell membrane (NCAM). NCAM is involved in cell-cell interactions during synaptogenesis, morphogenesis, and plasticity of the nervous system. We studied the expression of these markers in the human adrenocortical carcinoma cell line $\mathrm{NCl}-\mathrm{H} 295$.

The cells were grown at $37^{\circ} \mathrm{C}$ in a $5 \% \mathrm{CO}_{2}$ humidified atmosphere in RPMI 1640 Medium (Gibco BRL, Eggenstein, Germany) containing hydrocortison $(3.625 \mathrm{mg} / \mathrm{l})$, insulin $5 \mathrm{mg} / \mathrm{l}$, transferrin $(10 \mathrm{mg} / \mathrm{ml})$, $\beta$-estradiol $(2.742 \mathrm{mg} / \mathrm{l})$, selenite ( $5 \mathrm{mg} / \mathrm{ml}$ ), 2\% fetal calf serum (all obtained from Sigma Aldrich, Deisenhofen, Germany) and antibiotics. For immunocharacterization antibodies against NCAM (mouse anti-human NCAM, clone NCAM-OB11,Sigma Aldrich, Deisenhofen, Germany) and synaptophysin (mouse anti-human, Dako, Hamburg, Germany) were used.

The human adrenocortical cell line $\mathrm{NCl}-\mathrm{H} 295$ expressed neuroendocrine features as revealed by immunohistochemistry and Western blotting. The cells exhibited strong NCAM immunoreactivity, which was confined to their cell surfaces and was particulary intense at cell - cell contact sites (Figs. 1a,c). The major molecular form expressed by NCI-H295 cells was the $140 \mathrm{kDa}$ band. The $180 \mathrm{kDa}$ band was not present(Fig. 2). In addition, these cells showed a cytoplasmic immunostaining for NSE (not shown) and synaptophysin, a protein associated with the membrane of synaptic vesicles (Figs. 1 b, d). Synaptophysin immunoreactivity from $\mathrm{NCI}$ cells is identical to synaptophysin from rat or human cortex with a molecular weight of $38 \mathrm{kDa}$ (Fig. 3). 


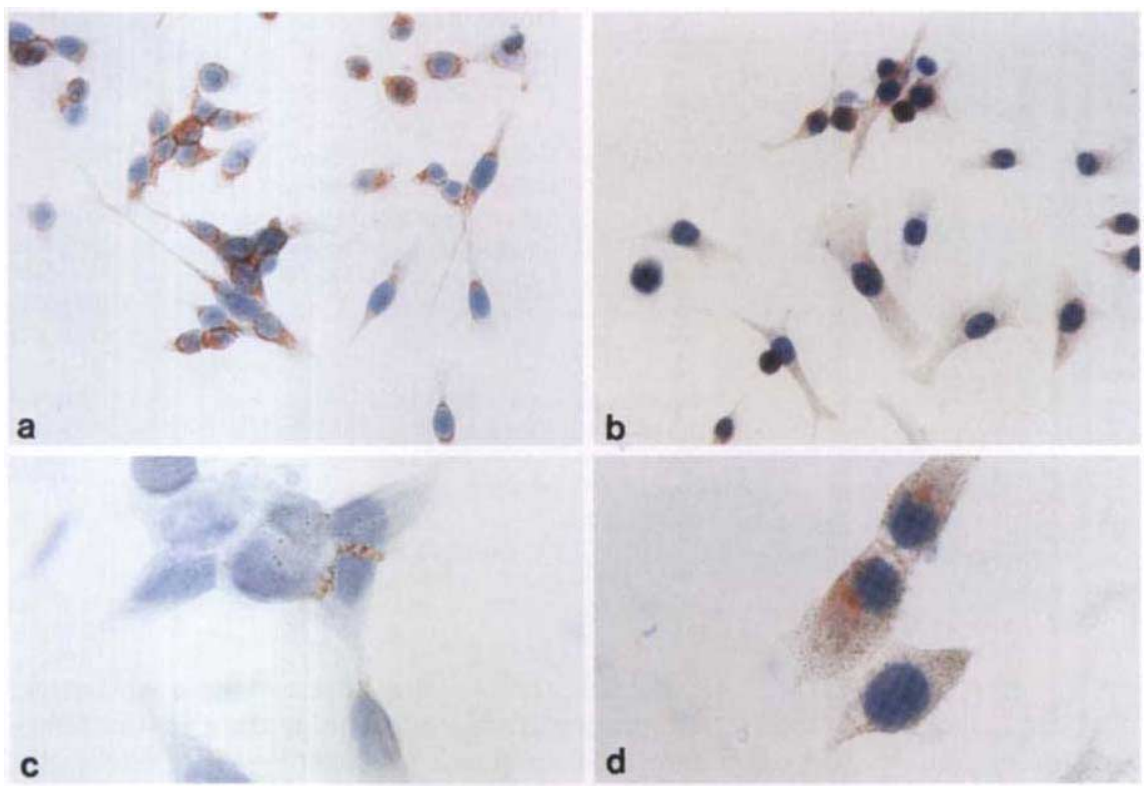

Fig. $1 \mathrm{NCl}-\mathrm{H} 295$ cells immunstained for $\operatorname{NCAM}(\mathbf{a}, \mathbf{c})$ or synaptophysin $(\mathbf{b}, \mathbf{d})$ using ACE (3-amino-9-ethylcarbazole) chromogen (Immunotech, Hamburg, Germany) and were counterstained with hematoxylin. Control staining was performed with mouse $\mathrm{lgC}$ instead of the primary antibodies and no unspecific staining was detectable (not shown). a, b: $\times 200$; c, d: $\times 540$.

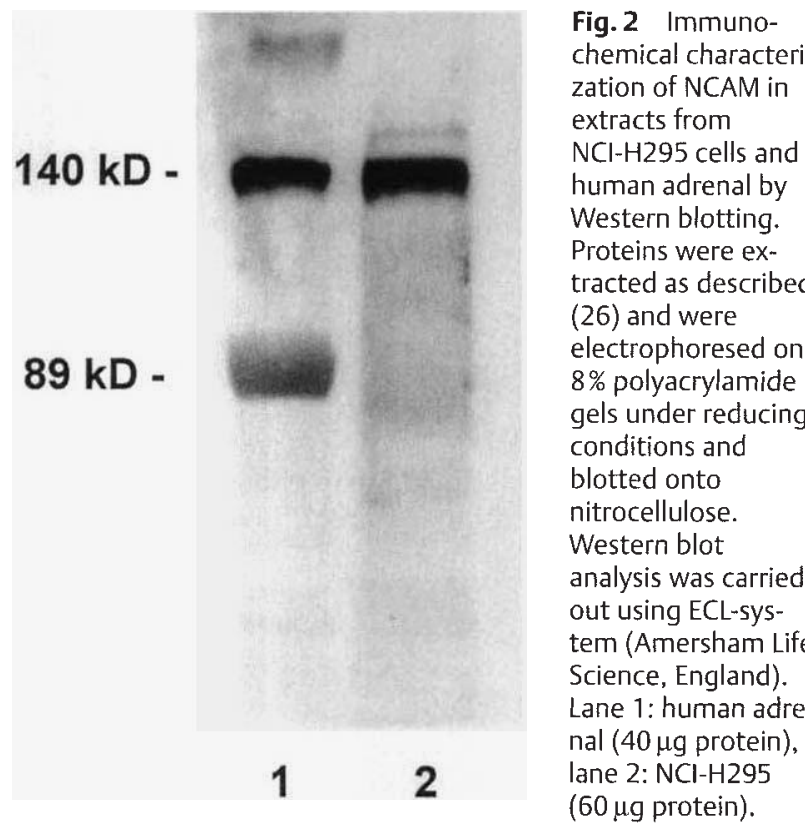

Is there evidence for a neuroendocrine differentiation in normal adrenocortical cells?

In addition to the carcinoma cell line, NCAM was immunohistochemically stained in normal human adrenals. Besides the expression on adrenomedullary chromaffin cells, NCAM was localized in the adrenal cortex (Fig. 4). In the rabbit (7) and the human adrenal cortex (Fig. 4), staining was restricted to the cells of the zona glomerulosa with no staining of other zone cells, while staining of all zones was observed in the rat adrenal cortex (8). The antibody used on our studies binds to the high molecular weight forms of NCAM. In normal human adrenals as well as in $\mathrm{NCl}-\mathrm{H} 295$ cells, the $140 \mathrm{kDa}$ form of NCAM predominates while the $180 \mathrm{kDa}$ form was not present (Fig. 2). Therefore, the adrenocortical carcinoma cells express the same pattern of NCAM, as does the adrenal medulla and

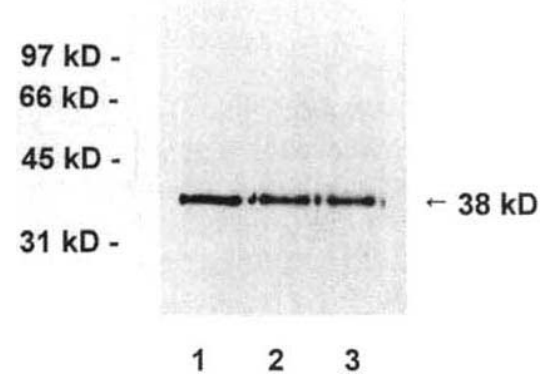

Fig. 3 Immunochemical characterization of synaptophysin in extracts from NCl-H295 cells and human adrenal by Western blotting. Proteins were extracted as described (26) and were electrophoresed on $10 \%$ polyacrylamide gels under reducing conditions and blotted onto nitrocellulose. Western blot analysis was carried out using ECL-system. Lane 1: rat cortex ( $20 \mu \mathrm{g}$ protein), lane 2: human cortex

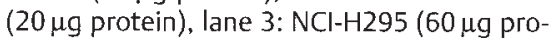
tein).

other neuroendocrine tissues $(9,10)$. In contrast to the adrenal medulla, NCAM on zona glomerulosa cells seems not to be highly sialated, since immunostaining for polysialic acid was restricted to the adrenal medulla and adrenal nerves in the normal human adrenal with no staining in the cortex (11).

It was suggested that the expression of NCAM especially, on cells of the zona glomerulosa, reflects the regenerative feature of these cells and that they lose NCAM immunoreactivity after moving to the zona fasciculata (8). However, together with other data on neuroendocrine properties of zona glomerulosa cells, NCAM expression on these cells may reflect a neuroendocrine differentiation of these cells.

There is increasing evidence that the cells of the zona glomerulosa indeed share characteristics with neuroendocrine cells 


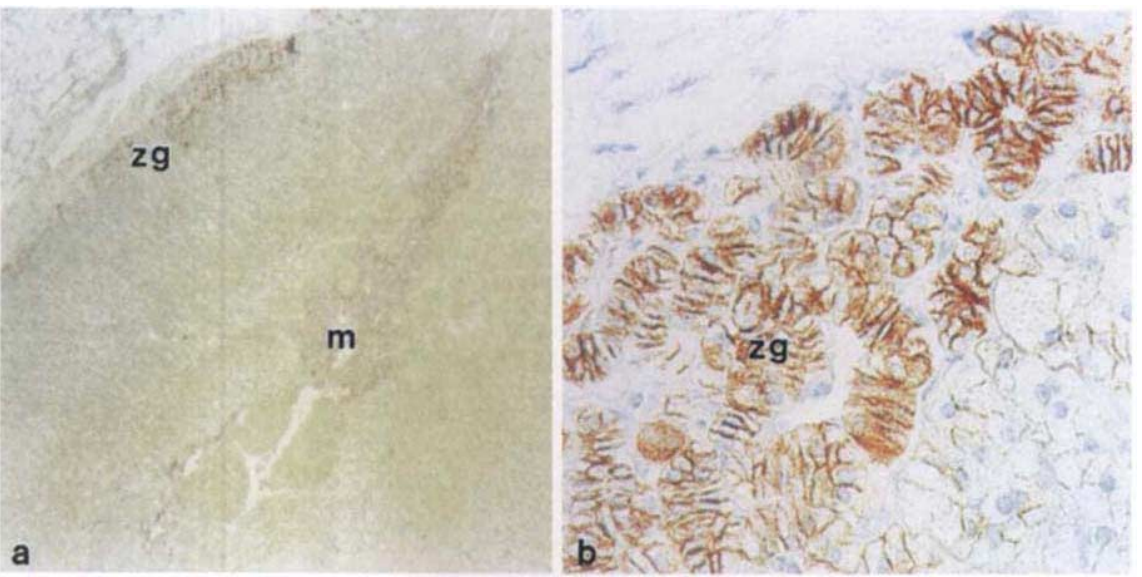

Fig. 4 Paraffin sections of human adrenals immunostained for NCAM. Immunostaining was carried out using 4-amino-9-ethylcarbazole (AEC; Dinanova, Hamburg Germany) as described previously ( 1 ) and were counterstained with hematoxylin. Staining for NCAM was restricted to the zona glomerulosa $(\mathrm{zg})$ and the adrenal medulla $(m) ; \mathbf{a}: \times 20 ; \mathbf{b}: \times 200$.

including the production of neuropeptides. Adrenomedullin is a novel hypotensive peptide that has originally been isolated from a human pheochromocytoma (12) and was immunohistochemically located to the adrenal medulla (13). Recent immunohistochemistry and in situ hybridization studies now showed that, in addition to the adrenal medulla, adrenocortical cells of the rat adrenal zona glomerulosa produce this peptide (14). Given the regulatory influence of adrenomedullin on aldosterone secretion (article by J. P. Hinson in this issue), adrenomedullin may have an autocrine role in the regulation of the adrenal zona glomerulosa. In addition, another peptide that influences adrenocortical steroidogenesis, the vasoactive intestinal polypeptide (VIP) was shown to be produced by cells of the zona glomerulosa (15). Therefore, in the normal adrenal cortex, the cells of the zona glomerulosa, in addition to their function as steroid-producing cells, produce peptides that are typically produced by neuroendocrine cells including adrenomedullary cells. These cells therefore share neuroendocrine properties with adrenomedullary cells. Another factor shared by adrenocortical and adrenomedullary cells is a zona glomerulosa specific factor that has recently been identified $(16,17)$. This membrane-spanning protein that has been cloned from zona glomerulosa cells is structurally related to the Notch and Delta superfamily (17), proteins involved in neurogenesis (18). In the adrenal cortex, this protein is present in zona glomerulosa cells exclusively. However, in addition to this location, this factor is produced by the chromaffin cells of the adrenal medulla and is therefore another protein shared by adrenocortical cells and neuroendocrine cells. This factor is also expressed in human adrenal tumor tissue, such as aldosteronoma and pheochromocytoma $(16,17)$.

Such a neuroendocrine differentiation is not restricted to the steroid-producing cells of the zona glomerulosa but has also been observed in other steroidogenic cells. In the testes, NCAM was shown on the cell membrane of Leydig cells $(19,20)$. In addition, a subpopulation of Leydig cells expresses neuroendocrine peptides and proteins that could influence Leydig cell function in an autocrine manner (21). These data even led to the suggestion that Leydig cells belong to the diffuse neuroendocrine system (DNES) (22). Like adrenocortical carcinomas, human Leydig cell tumors express neuroendocrine markers and may therefore originate from the subset of Leydig cells with neuroendocrine nature (21).
As with Leydig cell tumors, the observed neuroendocrine properties of adrenocortical tumors implicated that adrenocortical tumors may originate from zona glomerulosa cells with a neuroendocrine differentiation (5). This origin would explain the very common involvement of the adrenal cortex in the multiple endocrine neoplasia Type 1 (MEN-1) syndrome $(5,23)$, although the adrenal cortex is not considered to be an intrinsic part of the diffuse neuroendocrine system (24). In addition, a long list of clinical data describes patients with adrenal cortical tumors clinically mimicking pheochromocytoma (for review [2]). While these observations in many cases can probably be explained by a paracrine stimulation of the adrenal medulla by the adrenal cortical tumor,-a neuroendocrine differentiation of these adrenocortical carcinomas with dense cored granules in the tumors themselves has also been described $(6,25)$.

In conclusion, the expression of neuroendocrine properties in adrenocortical cells and other steroid-producing cells seems to be a common phenomenon, and may have important clinical implications, besides its involvement in autocrine regulations of steroidogenesis.

\section{Acknowledgements}

This work was supported by the Wilhelm Sander Stiftung (grant 95.033.1 to MEB).

\section{References}

1. Haidan A, Bornstein SR, Glasow A, Uhlmann K, Lübke C, EhrhartBornstein M. Basal steroidogenic activity of adrenocortical cells is increased tenfold by co-culture with chromaffin cells. Endocrinology 1998; 139: 772-80

2. Ehrhart-Bornstein M, Hinson JP, Bomstein SR, Scherbaum WA, Vinson GP. Intra-adrenal interactions in the regulation of adrenocortical steroidogenesis. Endocr Rev 1998; 19: $101-43$

3. Schröder S, Padberg BC, Achilles E, Holl K, Dralle H, Kloppel G. Immunocytochemistry in adrenocortical tumours: a clinicomorphological study of 72 neoplasms. Virchows Arch A Pathol Anat Histopathol 1992; 420: 65-70

4. Bornstein SR, Brown JW, Carballeira A, Goodman J, Scherbaum WA, Fishman LM. Ultrastructural dynamics of mitochondrial morphology in varying functional forms of human adrenal cortical adenoma. Horm Metab Res 1996; 28: 177-82 
5. Haak HR, Fleuren GJ. Neuroendocrine differentiation of adrenocortical tumors. Cancer 1995; 75: 860-4

6. Miettinen M. Neuroendocrine differentiation in adrenocortical carcinoma. New immunohistochemical findings supported by electron microscopy. Lab Invest 1992; 66: $169-74$

7. Moftaquir A, Langley K, Boutroy MJ. Immunocytochemical localization of NCAM and catecholamine-synthesizing enzymes in rabbit intra- and extra-adrenal chromaffin tissue. Histochem J 1996; 28: $661-9$

8. Lahr G, Mayerhofer A, Bucher S, Barthels D, Wille W, Gratzl M. Neural cell adhesion molecules in rat endocrine tissues and tumor cells: distribution and molecular analysis. Endocrinology $1993 ; 132 ; 1207-17$

9. Langley OK, Aletsee MC, Gratzl M. Endocrine cells share expression of N-CAM with neurons. FEBS Lett 1987; 220: 108-12

10. Langley K, GratzI M. Neural adhesion molecule NCAM in neural and endocrine cells. In: Gratzl M, Langley K (eds). Markers for Neural and Endocrine Cells. Molecular and Cell Biology, Diagnostic Applications. Verlag Chemie, Weinheim 1990: 133 - 78

11. Komminoth P, Roth J, Schröder S, Saremaslani P, Heitz PU. Overlapping expression of immunohistochemical markers and synaptophysin mRNA in pheochromocytomas and adrenocortical carcinomas. Lab Invest 1995; 72: 424-31

12. Kitamura K, Kangawa K, Kawamoto M, Ichiki Y, Nakamura S, Matsuo H, Eto T. Adrenomedullin: a novel hypotensive peptide isolated from human adrenal. Biochem Biophys Res Commun 1993; 192: $553-60$

13. Washimine $H$, Asada $Y$, Kitamura K, Ichiki Y, Hara S, Yamamoto Y, Kangawa K, Sumiyoshi A, Eto T. Immunohistochemical identification of adrenomedullin in human, rat and porcine tissues. Histochemistry 1995; 103: $251-4$

14. Kapas S, Martinez A, Cuttitta F, Hinson JP. Local production and action of adrenomedullin in the rat adrenal zona glomerulosa. J Endocrinol 1997 (in press)

15. Hinson JP, Kapas S. Regulation of vasoactive intestinal peptide in the rat adrenal gland. $10^{\text {th }}$ International Congress of Endocrinology, San Francisco P1 - 361, 1996 (abstract)

16. Halder SK, Takemori H, Hatano O, Okamoto M. A transmembrane protein specifically expressed in zona glomerulosa. Endocr Res 1996; 22: 407-8

17. Okamoto $\mathrm{M}$, Takemori $\mathrm{H}$, Halder SK, Hatano O. Zona glomerulosa-specific factor: cloning and function. Steroids 1997; 62: $73-$ 6

18. Huttner WB, Brand M. Asymetric division and polarity of neuroepithelial cells. Curr Opin Neurobiol 1997; 7: 29-39

19. Mayerhofer A, Seidl K, Lahr G, Bitter-Suermann D, Christoph A, Barthels D, Wille W, Gratzl M. Leydig cells express neural cell adhesion molecules (NCAMs) in vivo and in vitro. Biol Reprod 1992; 47: 656-64

20. Mayerhofer A, Lahr G, Seidl K, Eusterschulte B, Christoph A, Gratzl M. The neural cell adhesion molecule (NCAM) provides clues to the development of testicular Leydig cells. J Androl 1996; $17: 223-30$

21. Middendorff R, Davidoff M, Holstein AF. Neuroendocrine marker substances in human Leydig cells - changes by disturbances of testicular function. Andrologia 1993; 25: 257-62

22. Davidoff MS, Schulze W, Middendorff R, Holstein AF. The Leydig cell of the human testis - a new member of the diffuse neuroendocrine system. Cell Tissue Res 1993; 271: 429-39

23. Lips CJM, Vasen HFA, Lamers CBHW. Multiple endocrine neoplasia syndromes. Crit Rev Oncol Hematol 1984; 2: 117-84

24. Nylen ES, Becker KL. The diffuse neuroendocrine system. In: Becker KL (ed). Principles and Practice in Endocrinology and Metabolism. Philadelphia: J.B. Lippincott Company, 1990: $1276-83$
25. Alsabeh R, Mazoujian G, Goates J, Medeiros LJ, Weiss LM. Adrenal cortical tumors clinically mimicking pheochromocytoma. Am J Clin Pathol 1995; 104: 382 - 90

26. Goetzl EJ, Patel DR, Kishiyama JL, Smoll AC, Turck CW, Law NM, Rosenzweig SA, Sreedharan SP. Specific recognition of the human neuroendocrine receptor for vasoactive intestinal peptide by anti-peptide antibodies. Mol Cell Neurosci 1994; 5: 145-52

Requests for reprints should be addressed to:

Monika Ehrhart-Bornstein, Ph.D.

$\mathrm{NIH}, \mathrm{NICHD}$

Building 10

Room 10 N262

Bethesda, MD 20892

USA 